\title{
Frequency of personality types based on enneagram in a Turkish sample: A web-based cross-sectional study
}

\section{Türkçe bir örneklemde enneagrama dayalı kişilik tiplerinin sıklığı: Web tabanlı kesitsel bir çalısma}

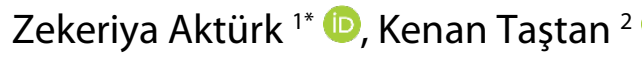 \\ 1 ailem Academic Counseling, Izmir, Turkey \\ ${ }^{2}$ Atatürk University Medical Faculty, Department of Family Medicine, Erzurum, Turkey \\ * Corresponding author: Zekeriya Aktürk E-mail: info@aile.net ORCID: 0000-0002-9772-3285 \\ Received: 4 March 2020 Accepted: 24 March 2020
}

\begin{abstract}
Objectives: Although the Enneagram is known for hundreds of years, research in this area is scarce. The purpose of this study was to analyze the frequency of personality types of a Turkish-speaking sample and compare the rates of different personalities with demographic data.

Methods: The Tastan Personality Types Inventory, an instrument based on Enneagram, was hosted at Google Forms and made available via the university's academic web page. Online responses were collected between 08.04.2015 and 22.8.2019. Participants of the study were Turkish speaking people aged adolescents and adults.

Results: Results for 1646 participants were analyzed. The mean $( \pm S D)$ age was $29.48 \pm 11.03$ years. The most commonly encountered main personality type was number 2 , "the helper," $(n=335,20.4 \%)$, while number 8 , "the challenger" was the most frequently encountered personality wing $(284,17.3 \%)$. The frequency of type 8 personality was decreasing with increasing age, while the reverse was true for type 3 personality $\left(x^{2}=130.623, p<0.001\right)$. While the type 1 personality was more common among males $(n=51(9.5 \%)$ vs. $n=63(5.7 \%))$, the type 4 was almost twice common among females $(n=48$ $(8.9 \%$ vs. $n=183(16.5 \%))\left(X^{2}=28.835, p<0.001\right)$. Also, the probability of type 1 personality was increasing as the level of education increased $\left(x^{2}=67.316, p<0.001\right)$.
\end{abstract}

Conclusion: There are differences in the personality types of the studied population concerning demographic variables. These findings imply that personality is not a lifelong constant entity, but it can change with age and education. Further studies should investigate the relationship of the Enneagram personality types with certain disease entities in defined populations.

Keywords: personality, personality assessment, psychometrics

() 2020 by the authors; licensee MEDITAGEM Ltd., Turkey. This article is an open access article distributed under the terms and conditions of the Creative Commons Attribution License (http://creativecommons.org/licenses/by/4.0/). 


\section{ÖZ}

Amaç: Enneagram yüzlerce yıldır bilinmesine rağmen, bu alandaki araştırmalar azdır. Bu çalışmanın amacı Türkçe konuşan bir örneklemin kişilik tiplerinin sıklığını analiz etmek ve farklı kişiliklerin oranlarını demografik verilerle karşılaştırmaktır.

Yöntem: Enneagram'a dayalı bir araç olan Taştan Kişilik Tipleri Envanteri Google Formlar'da barındırıldı ve üniversitenin akademik web sayfası üzerinden kullanıma sunuldu. Çevrimiçi yanıtlar 08.04.2015 ve 22.8.2019 tarihleri arasında toplanmıştır. Çalışmanın katılımcıları Türkçe konuşan ergenler ve yetişkinlerdir.

Bulgular: Bu araştırmada 1646 katılımcının verileri analiz edildi. Ortalama ( \pm SD) yaş 29,48 \pm 11,03 yıl idi. En sık karşılaşılan ana kişilik tipi 2 numaralı "yardımcı" ( $n=335, \% 20,4), 8$ numaralı "meydan okuyucu" ise en sık karşılaşılan kişilik kanadıdır $(284, \% 17,3)$. Tip 8 kişilik sıklığı artan yaşla birlikte azalırken, tip 3 kişilik için tersi doğruydu $\left(x^{2}=130,623, p<0,001\right)$. Tip 1 kişilik erkeklerde daha yaygın iken $(n=51(\% 9,5)$ ve $n=63(\% 5,7))$, tip 4 kadınlarda neredeyse iki kat fazlaydı $\left(n=48\left(\% 8,9^{\prime}\right.\right.$ a karşılık $n=183(\% 16,5))\left(x^{2}=28,835, p<0,001\right)$ Ayrıca, eğitim düzeyi arttıkça tip 1 kişilik olasılığı da artmaktadır ( $x^{2}=67,316$, $\mathrm{p}<0,001)$.

Sonuç: İncelenen nüfusun kişilik tiplerinde demografik değişkenler açısından farklılıklar vardır. Bu bulgular kişilik tipinin beşikten mezara kadar aynı olmadığını, eğitim ve yaşla değişebileceğini düşündürmektedir. Enneagram kişilik tiplerinin tanımlanmış popülasyonlardaki belirli hastalıklarla ilişkisi araştırmalıdır.

Anahtar kelimeler: kişilik, kişilik değerlendirmesi, psikometri

\section{INTRODUCTION}

\section{Background and Rationale}

Knowing the personality traits has advantages for the person as well as the people in contact [1]. It will not only help to facilitate communication and establish a favorable dialogue between people, but can also aid professionals in psychology, medicine [2], arts, business, and education. Some have suggested the use of personality traits in personnel recruitment, sales, and marketing [3]. Personality traits have been hypothesized to be clinically useful for diagnosis, client conceptualization, treatment planning, as well as for predicting treatment outcomes, potential strengths, and barriers to treatment [4].

Standardized psychometric tests of adult personality and psychopathology such as the Minnesota Multiphasic Personality Inventory [5], the Five-Factor Model [6], Zuckerman-Kuhlman Personality Questionnaire [7], Temperament and Character Inventory [8], and Kupfer Detre Scale [9], were utilized by health professionals as part of their assessment procedures. Although the Enneagram principles are known in Europe since the 1920s [10], its use has not become widespread, partly due to missing appropriate measurement scales [11].

The Enneagram of Personality is a concept categorizing using nine interconnected personality types [12]. It was suggested that the Enneagram can serve as a tool for understanding the ideas and behaviors of others as well as improving relationships with family, friends, and co-workers [13]. The Enneagram proposes explanations of why a person acts in a certain way and recommends directions for individual growth [3].

Although the Enneagram is known since ancient times [14], the assessment of an individual requires experience and time. Hence, it was not widely employed as a psychometric measurement tool. However, there are recent efforts to develop scales measuring temperament based on the Enneagram [11,15].

\section{Objectives}

The purpose of this study was to analyze the frequency of personality types of a Turkish-speaking sample and compare the frequencies of different personalities with demographic data.

\section{METHODS}

\section{Study Design}

The study was conducted in a descriptive, cross-sectional design between 08.04.2015 and 22.8.2019. Study reporting was done following the STROBE guidelines [16]. This study has been approved by the Ataturk University Faculty of Medicine Clinical Research Ethics Committee (No: B.30.2.ATA.0.01.00/168-Date:10.24.2016). 
Table 1. Internal consistency of the inventory and its subscales

\begin{tabular}{|c|c|c|}
\hline Component & Number of items & Cronbach's alpha \\
\hline 1 & 5 & 0.631 \\
\hline 2 & 4 & 0.379 \\
\hline 3 & 6 & 0.811 \\
\hline 4 & 5 & 0.809 \\
\hline 5 & 5 & 0.676 \\
\hline 6 & 4 & 0.618 \\
\hline 7 & 4 & 0.835 \\
\hline 8 & 6 & 0.740 \\
\hline 9 & 5 & 0.810 \\
\hline Total & 44 & 0.866 \\
\hline
\end{tabular}

\section{Setting}

The Tastan Personality Types Inventory (TPTI) [11] was hosted at Google Forms (https://docs.google.com/forms/ d/e/1FAIpQLSeN90dTISi43Bjh4GRX7zDc01 cow4hcpTrn0Ao 2Eab7E4rm5g/viewform) and made available via the university's academic web page http://aile.atauni.edu.tr. Responses were collected online. A note on the purpose of data collection was included in the form.

\section{Variables}

The primary outcome variable of the study was the leading personality type, as defined by the TPTI [11]. Additionally, demographic questions included were age, sex, educational status, occupation, and city of residence.

The TPTI uses 44 questions to identify the leading personality and one personality wing based on the Enneagram theory [14]. Scoring of the TPTI is made by a 7point Likert scale, ranging from 0 (Strongly No) to 6 (Strongly Yes). All items of the inventory are positively scored. The mean scores of the nine components and a total score by adding all component scores were calculated. The Cronbach's alpha internal consistency score for all 44 items, and the nine dimensions are given in Table 1.

\section{Bias}

Since the questionnaire was self-applied, one can assume an anonymous atmosphere. However, interference by third persons during data entry cannot be precluded. Nevertheless, we performed detailed post-hoc data checking and debugging to minimize bias.

\section{Participants}

Participants of this study are Turkish speaking people who randomly or with some advice accessed the data collection tool on the World Wide Web. Responses for the years 2015, 2016, 2017, 2018, and 2019 were 699, 788, 136, 333, and 549, respectively (Total 2505 entries). Records with matching

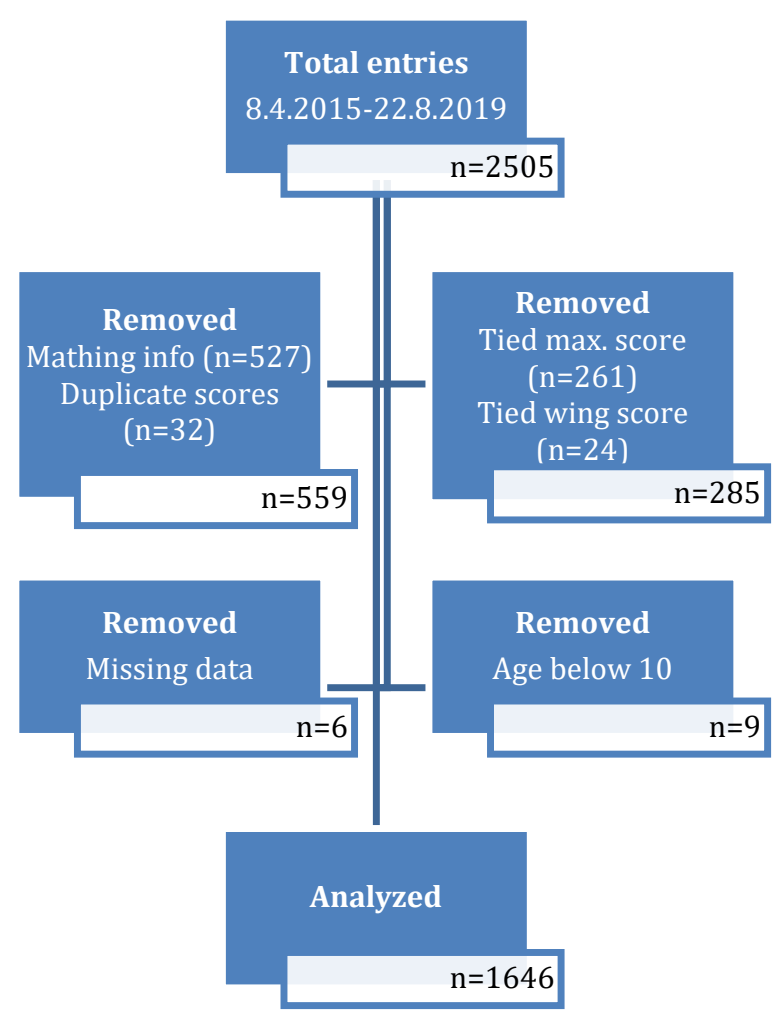

Figure 1. Study flow diagram

age, sex, and e-mails ( $n=526 ; 21.0 \%)$ were accepted as repeated entries, of which all except the last entry were deleted. Also, records with duplicating scores for all domains $(n=32 ; 1.6 \%)$ were considered as entries by the same person and removed.

The automatic scoring algorithm could not decide on the primary personality type for 261 participants, who had tied maximum scores. These and additional 24 participants with tied wing scores could not be categorized by the computer and thus, removed. Lastly, 9 participants below 10 years and 7 participants with missing data (age, sex) were excluded, ending up with 1646 participants for analysis (Figure 1).

\section{Study Size}

The sample size of the population was calculated based on the primary outcome "Main personality type." To compare the nine personality types between two groups using ChiSquare with an effect size of 0.14 (low), an alpha error of 0.05 , and a power of 0.99 , a total sample size of 1602 participants is required [17].

\section{Statistical Methods}

The data were analyzed using the Statistical Package for the Social Sciences (SPSS) version 25.0 software (SPSS Inc., Chicago, IL, USA). The results were presented as frequencies, percentages, means, and standard deviations (SD). The Kolmogorov-Smirnov test was performed to test if the 
Table 2. Demographic characteristics of the participants

\begin{tabular}{|c|c|c|c|}
\hline & & $n$ & $\%$ \\
\hline \multirow{2}{*}{ Sex } & Female & 1107 & 67.3 \\
\hline & Male & 539 & 32.7 \\
\hline \multirow{6}{*}{ Occupation } & $\begin{array}{l}\text { White collar employee with bachelor } \\
\text { degree }\end{array}$ & 428 & 26.0 \\
\hline & Teacher & 225 & 13.7 \\
\hline & Government officer & 221 & 13.4 \\
\hline & Blue collar worker and housewives & 187 & 11.4 \\
\hline & Student & 553 & 33.6 \\
\hline & Unemployed & 32 & 1.9 \\
\hline \multirow{6}{*}{ Education } & Primary school & 46 & 2.8 \\
\hline & Secondary school & 114 & 6.9 \\
\hline & High school & 195 & 11.8 \\
\hline & University & 1022 & 62.1 \\
\hline & Masters & 179 & 10.9 \\
\hline & PhD & 90 & 5.5 \\
\hline \multirow{8}{*}{$\begin{array}{c}\text { Geographical } \\
\text { Area }\end{array}$} & Mediterranean & 90 & 8.3 \\
\hline & East Anatolia & 129 & 11.9 \\
\hline & Aegean & 177 & 16.3 \\
\hline & South-East Anatolia & 213 & 19.6 \\
\hline & Central Anatolia & 184 & 16.9 \\
\hline & Marmara & 220 & 20.3 \\
\hline & Black sea & 59 & 5.4 \\
\hline & Outside Turkey & 14 & 1.3 \\
\hline
\end{tabular}

Table 3. Distributions of the primary personality types

\begin{tabular}{|c|c|c|c|c|}
\hline & & & $\begin{array}{l}\text { TPTI S } \\
\text { primary }\end{array}$ & $\begin{array}{l}\text { of the } \\
\text { onality }\end{array}$ \\
\hline Personality type & Frequency & Percent & Mean & SD \\
\hline 1-The perfectionist & 114 & 6.9 & 4.97 & 0.75 \\
\hline 2-The helper & 335 & 20.4 & 5.17 & 0.69 \\
\hline 3-The achiever & 204 & 12.4 & 5.21 & 0.66 \\
\hline 4-The romantic & 231 & 14.0 & 5.30 & 0.65 \\
\hline 5-The observer & 136 & 8.3 & 5.22 & 0.68 \\
\hline 6-The loyalist & 47 & 2.9 & 5.19 & 0.66 \\
\hline 7-The adventurer & 247 & 15.0 & 5.44 & 0.60 \\
\hline 8-The challenger & 95 & 5.8 & 5.18 & 0.73 \\
\hline 9-The peacemaker & 237 & 14.4 & 5.27 & 0.62 \\
\hline Total & 1646 & 100.0 & & \\
\hline
\end{tabular}

numerical variables were normally distributed. The independent samples t-test and one-way ANOVA with post hoc Tukey test were used to compare numerical data. The Chi-Square test was used to compare categorical variables. A p-value of $<0.05$ was considered statistically significant.

\section{RESULTS}

\section{Participants}

Results for 1646 participants were analyzed. The mean ( \pm SD) age was $29.48 \pm 11.03$ years (min. 10, max. 72 ). More women took part in the study than men. Also, university students comprised a significant portion of the sample. Responses
Table 4. Distribution of the personality wings

\begin{tabular}{|c|c|c|c|c|}
\hline & & & \multicolumn{2}{|c|}{$\begin{array}{c}\text { TPTI Score of the wing } \\
\text { personality }\end{array}$} \\
\hline & Frequency & Percent & Mean & SD \\
\hline 1 & 289 & 17.6 & 3.96 & 0.89 \\
\hline 2 & 224 & 13.6 & 4.33 & 0.76 \\
\hline 3 & 289 & 17.6 & 4.30 & 0.89 \\
\hline 4 & 170 & 10.3 & 4.22 & 0.97 \\
\hline 5 & 182 & 11.1 & 4.20 & 0.93 \\
\hline 6 & 69 & 4.2 & 3.78 & 0.98 \\
\hline 7 & 79 & 4.8 & 4.06 & 1.07 \\
\hline 8 & 284 & 17.3 & 4.00 & 1.00 \\
\hline 9 & 60 & 3.6 & 3.99 & 0.98 \\
\hline Total & 1646 & 100.0 & & \\
\hline & & & & \\
\hline
\end{tabular}

came from all seven geographical regions of Turkey and even a few from outside Turkey (Table 2).

\section{Descriptive Data}

The most commonly encountered primary personality type was number 2, "the helper," while number 8, "the challenger" was the most frequently encountered personality wing (Tables 3 and $\mathbf{4}$ ).

\section{Outcome Data}

Frequencies of the primary personality types showed significant differences concerning different demographic features. As examples of some remarkable findings, the rate of type 8 personality was decreasing with increasing age, while the reverse was true for type 3 personality. The type 2 personality was predominantly stronger both among males and females. However, while the type 1 personality was more common among males, the type 4 was almost twice common among females. Also, the probability of type 1 personality was increasing as the level of education increased. On the other hand, the occupation was related to the type of personality too. While all participants had more type 2 personalities, this trait was highest among the unemployed (Table 5).

The mean TPTI scores concerning the main personality types were different. Participants with type 5 personality had significantly higher mean scores compared to the types 1 (Tukey p 0.010) and 6 (Tukey p 0.040). Participants with type 5 personality had the highest scores, while people with type 6 personality had the lowest scores (Figure 2).

\section{DISCUSSION}

\section{Key Results}

This study demonstrated that the most commonly encountered leading personality type in the studied 
Table 5. Differences in the main personality types

\begin{tabular}{|c|c|c|c|c|c|c|c|c|c|c|c|c|c|c|c|c|c|c|c|c|}
\hline & \multicolumn{18}{|c|}{ Main Personality Type } & \multirow[b]{3}{*}{$x^{2}$} & \multirow[b]{3}{*}{$p$} \\
\hline & \multicolumn{2}{|c|}{1} & \multicolumn{2}{|c|}{2} & \multicolumn{2}{|c|}{3} & \multicolumn{2}{|c|}{4} & \multicolumn{2}{|c|}{5} & \multicolumn{2}{|c|}{6} & \multicolumn{2}{|c|}{7} & \multicolumn{2}{|c|}{8} & \multicolumn{2}{|c|}{9} & & \\
\hline & $n$ & $\%$ & $\mathbf{n}$ & $\%$ & $\mathbf{n}$ & $\%$ & $n$ & $\%$ & $n$ & $\%$ & $n$ & $\%$ & $\mathbf{N}$ & $\%$ & $n$ & $\%$ & $\mathbf{n}$ & $\%$ & & \\
\hline Age groups (years) & & & & & & & & & & & & & & & & & & & 130.623 & $<0.001$ \\
\hline 19 and below & 22 & 7.2 & 72 & 23.7 & 17 & 5.6 & 52 & 17.1 & 19 & 6.3 & 9 & 3.0 & 55 & 18.1 & 30 & 9.9 & 28 & 9.2 & & \\
\hline $20-29$ & 42 & 6.6 & 121 & 19.1 & 49 & 7.7 & 103 & 16.2 & 72 & 11.4 & 18 & 2.8 & 105 & 16.6 & 42 & 6.6 & 82 & 12.9 & & \\
\hline $30-39$ & 25 & 6.9 & 74 & 20.4 & 65 & 17.9 & 44 & 12.1 & 24 & 6.6 & 15 & 4.1 & 42 & 11.6 & 13 & 3.6 & 61 & 16.8 & & \\
\hline $40-49$ & 21 & 7.9 & 46 & 17.2 & 54 & 20.2 & 23 & 8.6 & 16 & 6.0 & 4 & 1.5 & 37 & 13.9 & 9 & 3.4 & 57 & 21.3 & & \\
\hline 50 and above & 4 & 5.1 & 22 & 28.2 & 19 & 24.4 & 9 & 11.5 & 5 & 6.4 & 1 & 1.3 & 8 & 10.3 & 1 & 1.3 & 9 & 11.5 & & \\
\hline Sex & & & & & & & & & & & & & & & & & & & 28.835 & $<0.001$ \\
\hline Female & 63 & 5.7 & 237 & 21.4 & 134 & 12.1 & 183 & 16.5 & 84 & 7.6 & 31 & 2.8 & 158 & 14.3 & 59 & 5.3 & 158 & 14.3 & & \\
\hline Male & 51 & 9.5 & 98 & 18.2 & 70 & 13.0 & 48 & 8.9 & 52 & 9.6 & 16 & 3.0 & 89 & 16.5 & 36 & 6.7 & 79 & 14.7 & & \\
\hline Education & & & & & & & & & & & & & & & & & & & 67.316 & $<0.001$ \\
\hline Secondary sch. or below & 4 & 2.5 & 40 & 25.0 & 24 & 15.0 & 22 & 13.8 & 8 & 5.0 & 6 & 3.8 & 29 & 18.1 & 6 & 3.8 & 21 & 13.1 & & \\
\hline High school & 12 & 6.2 & 38 & 19.5 & 27 & 13.8 & 24 & 12.3 & 17 & 8.7 & 3 & 1.5 & 33 & 16.9 & 18 & 9.2 & 23 & 11.8 & & \\
\hline University & 68 & 6.7 & 210 & 20.5 & 97 & 9.5 & 161 & 15.8 & 91 & 8.9 & 32 & 3.1 & 153 & 15.0 & 59 & 5.8 & 151 & 14.8 & & \\
\hline Masters & 18 & 10.1 & 31 & 17.3 & 37 & 20.7 & 19 & 10.6 & 15 & 8.4 & 2 & 1.1 & 22 & 12.3 & 9 & 5.0 & 26 & 14.5 & & \\
\hline $\mathrm{PhD}$ & 12 & 13.3 & 16 & 17.8 & 19 & 21.1 & 5 & 5.6 & 5 & 5.6 & 4 & 4.4 & 10 & 11.1 & 3 & 3.3 & 16 & 17.8 & & \\
\hline Occupation & & & & & & & & & & & & & & & & & & & 104.874 & $<0.001$ \\
\hline $\begin{array}{l}\text { White collar with } \\
\text { bachelor }\end{array}$ & 38 & 8.9 & 88 & 20.6 & 65 & 15.2 & 56 & 13.1 & 28 & 6.5 & 14 & 3.3 & 51 & 11.9 & 24 & 5.6 & 64 & 15.0 & & \\
\hline Teacher & 14 & 6.2 & 37 & 16.4 & 30 & 13.3 & 33 & 14.7 & 18 & 8.0 & 8 & 3.6 & 36 & 16.0 & 11 & 4.9 & 38 & 16.9 & & \\
\hline Government officer & 13 & 5.9 & 37 & 16.7 & 39 & 17.6 & 24 & 10.9 & 19 & 8.6 & 4 & 1.8 & 40 & 18.1 & 14 & 6.3 & 31 & 14.0 & & \\
\hline $\begin{array}{l}\text { Blue collar and } \\
\text { housewives }\end{array}$ & 10 & 5.3 & 34 & 18.2 & 34 & 18.2 & 24 & 12.8 & 14 & 7.5 & 4 & 2.1 & 19 & 10.2 & 1 & 0.5 & 47 & 25.1 & & \\
\hline Student & 37 & 6.7 & 129 & 23.3 & 35 & 6.3 & 85 & 15.4 & 55 & 9.9 & 17 & 3.1 & 97 & 17.5 & 43 & 7.8 & 55 & 9.9 & & \\
\hline Unemployed & 2 & 6.3 & 10 & 31.3 & 1 & 3.1 & 9 & 28.1 & 2 & 6.3 & 0 & 0.0 & 4 & 12.5 & 2 & 6.3 & 2 & 6.3 & & \\
\hline
\end{tabular}

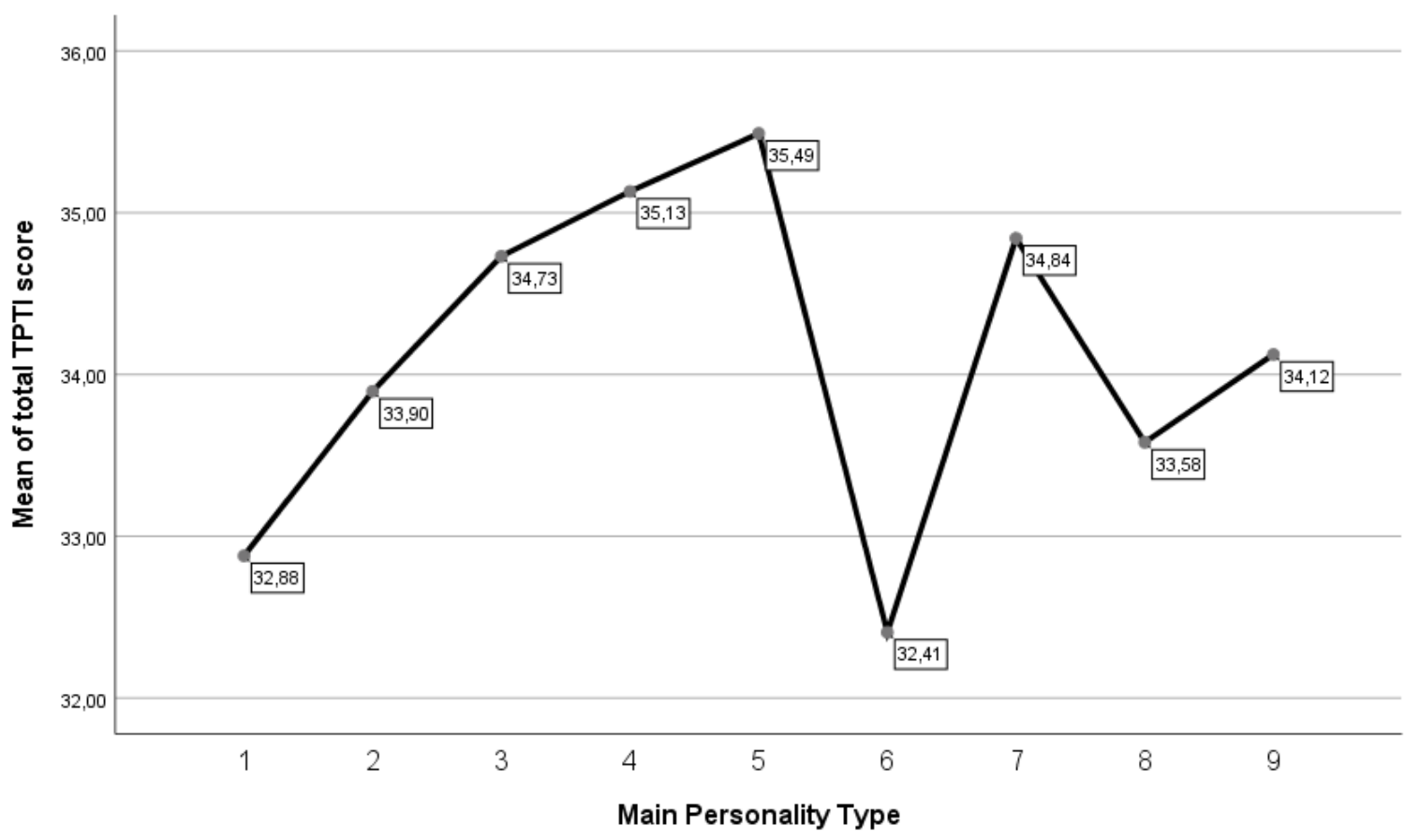

Figure 2. Mean TPTI scores of participants with different main personality types

population was number 2 , "the helper," while number 8 , "the challenger" was the most frequently encountered personality wing. On the other hand, the occupation was related to the type of personality too. Type 2 personality was strongest among the unemployed. The frequency of type 8 personality was decreasing with increasing age, while the reverse was true for type 3 personality. On the other hand, while the type 1 personality was more common among males, the type 4 was almost twice common among females. Also, the probability of type 1 personality was increasing as the level of education increased. 


\section{Interpretation}

The Enneagram assigns one primary temperament type and a wing personality to each individual. While number one "the perfectionist" personality type believes in the correctness of moral values, the number two "the helper" believes in his/her importance, number three "the achiever" strives for perfectness, number four "the romantic" gives importance to own freedom, number five "the observer" trusts in the power of knowledge, number six "the loyalist" emphasizes the trust provided by the people, number seven "the adventurer" gives importance to materiality, number eight "the challenger" counts for power, and number nine is called "the peacemaker" [3,14]. However, the personality of a person is a combination of all nine types [18].

The approach based on the personality type can be an advantage for healthcare providers, who recognize that each individual is different. Furthermore, the doctor's personality type preferences are often very different from those of the patients [19]. The Enneagram was used to predict healthy lifestyle changes. Researchers have investigated the relationship between Enneagram personality types and perceived risk of heart disease and readiness to lifestyle modification [20]. The achiever personality can have an increased willingness to lifestyle modification, while a reverse relationship was found between the challenger personality and readiness to lifestyle modification. It may be deducted that the Enneagram personality types may be used to check any kind of willingness to change.

In our study, the most commonly encountered primary personality type was number 2 , "the helper," while number 8 , "the challenger" was the most frequently encountered personality wing. As to the original study during the scale development, the most prevailing personality among the participants was found as personality number nine, the peacemaker [11]. Other researchers [12,21] consistently identified the number nine-personality type is the most frequent personality type. However, the populations studied in all the given studies consisted of university students, which make us postulate that there are transcountry similarities in the personality distributions but with variability between the different groups in the same country.

As remarkable findings, the frequency of type 8 personality in our study was decreasing with increasing age, while the reverse was true for type 3 personality. Although there is no available literature to interpret this finding, we considered it as an indicator that the personality traits are changing with age. The challenger side of a person may get rasped over time, while they may become more understandable and ready to help others as they get older, and, thus, wiser.

On the other hand, while the type 1 personality was more common among males, the type 4 was almost twice common among females. This finding might be related to the gender identities in the Turkish population [22]. Also, the probability of type 1 personality was increasing as the level of education increased. The type 1 personality was explained as "... are conscientious and ethical, with a strong sense of right and wrong. They are teachers, crusaders, and advocates for change: always striving to improve things, but afraid of making a mistake..." [23]. From this perspective, it might be expectable that education induces some change in the personality.

One study on medical students compared the Jefferson Scale of Empathy scores in different Enneagram personality groups [18]. It was revealed that type 2 and 6 students showed the two highest empathy scores, while the empathy score of type 3 students was the lowest. Also, it was demonstrated that an Enneagram group counseling program is effective in establishing positive selfidentification in nursing college students [12]. Although we found some differences in the personality types concerning the occupational groups with strikingly high proportions of type 2 personalities among the unemployed, this finding requires additional elaboration due to the relatively low number of participants in this group.

According to the Enneagram, the nine personality types can be further sub-categorized into different groups called the hornevian groups, and the harmonic groups [24]. In the current era of knowledge, increasingly, more responsibilities are transferred to the individuals concerning their own health. Thus, instruments such as the Enneagram scales may become reliable frameworks for understanding differences with patients, families, and co-workers [25].

\section{Study Limitations}

A significant limitation of this study is the relatively illdefined study population. Turkish speaking participants from anywhere could participate in the study. However, we achieved a high sample size that could collect responses coming from all seven geographical regions of Turkey. Also, due to the nature of data collection, the participants must have a certain level of computer literacy. Thus, the study cannot claim generalizability to the Turkish population but can give a strong idea about the general distribution of the Enneagram personality types in Turkey. Also, the 
measurement tool used [11] had high sensitivity and specificity, which can be considered as a strength of the study.

\section{Conclusion}

Our research indicates that the number 2 personality is the most frequent personality type among the studied Turkishspeaking population. Further studies should investigate the relationship of the Enneagram personality types with certain disease entities in specific communities using the main personality types, hornevian groups, and harmonic groups.

\section{DECLARATION OF CONFLICT OF INTEREST}

The authors received no financial support for the research and/or authorship of this article. There is no conflict of interest.

\section{REFERENCES}

1. Carlson EN. Meta-accuracy and relationship quality: Weighing the costs and benefits of knowing what people really think about you. J Pers Soc Psychol. 2016 Aug; 111(2): 250-64.

2. Guimond S, Massrieh W. Intricate correlation between body posture, personality trait and incidence of body pain: A cross-referential study report. PLoS One. 2012; $7(5)$.

3. Tastan K. [Combating Stress According to Personality Types]. Elazig: Grafikkent Dijital Baski Merkezi; 2012.

4. Bucher MA, Suzuki T, Samuel DB. A meta-analytic review of personality traits and their associations with mental health treatment outcomes. Clin Psychol Rev. 2019 Jun; 70: 51-63.

5. Butcher JN. Minnesota multiphasic personality inventory. Corsini Encycl Psychol. 2010: 1-3.

6. Song $Y$, Shi M. Associations between empathy and big five personality traits among Chinese undergraduate medical students. PLoS One. 2017; 12(2): e0171665.

7. Hojat M, Zuckerman M, Magee M, Mangione S, Nasca T, Vergare $M$, et al. Empathy in medical students as related to specialty interest, personality, and perceptions of mother and father. Pers Individ Dif. 2005; 39(7): 1205-15.

8. Lee BK, Bahn GH, Lee W-H, Park JH, Yoon TY, Baek S Bin. The relationship between empathy and medical education system, grades, and personality in medical college students and medical school students. Korean J Med Educ. 2009; 21(2): 117-24.
9. Kupfer DJ, Drew FL, Curtis EK, Rubinstein DN. Personality style and empathy in medical students. J Med Educ. 1978.

10. Ginsburg SB. Gurdjieff unveiled: an overview and introduction to Gurdjieff's teaching. London: Lighthouse Workbooks; 2005. 138 p.

11. Tastan K. Development and Validation of a Personality Type Inventory Based on Enneagram. Konuralp Tıp Derg. 2019; 11(1): 112-8.

12. Lee JS, Yoon JA, J DK. [Effectiveness of enneagram group counseling for self-identification and depression in nursing college students]. J Korean Acad Nurs. 2013; 43(5): 649-57.

13. Eckstein D. The Couple's Enneagram Questionnaire (CEQ). Fam J. 2002; 10(1): 101-8.

14. Baron R, Wagele E. The Enneagram Made Easy: Discover the 9 Types of People. New York: Harper Collins Publishers; 1994.

15. Yilmaz ED, Gencer AG, Aydemir O, Yilmaz A, Kesebir S, Unal $O$, et al. Validity and reliability of nine types temperament scale. Egit ve Bilim. 2014; 39(171): 115-37.

16. Von Elm E, Altman DG, Egger M, Pocock SJ, Gøtzsche PC, Vandenbroucke JP. The Strengthening the Reporting of Observational Studies in Epidemiology (STROBE) statement: Guidelines for reporting observational studies. PLoS Med. 2007; 4(10): 1623-7.

17. Faul F, Erdfelder E, Lang A-G, Buchner A. G*Power 3: A flexible statistical power analysis program for the social, behavioral, and biomedical sciences. Behav Res Methods. 2007.

18. Roh H, Park KH, Ko HJ, Kim DK, Son H Bin, Shin DH, et al. Understanding medical students' empathy based on Enneagram personality types. Korean J Med Educ. 2019 Mar; 31(1): 73-82.

19. Allen J, Brock SA, Ford S. Health care communication using personality type: patients are different! Heal Expect. 2002; 5(2): 182-3.

20. Komasi S, Zakiei A, Ghasemi SR, Gilan NR, Veisi A, Bagherirad $D$, et al. Is enneagram personality system able to predict perceived risk of heart disease and readiness to lifestyle modification? Ann Card Anaesth. 2019; 22(4): 394-9. 
21. Hur Y, Lee KH. Analysis of Medical Students' Enneagram Personality Types, Stress, and Developmental Level. Korean J Med Educ. 2011; 23(3): 175-84.

22. Sunar D, Fisek G. Contemporary Turkish families. Fam Glob Perspect. 2005: 169-83.

23. Riso DR, Hudson R. The wisdom of the Enneagram: The complete guide to psychological and spiritual growth for the nine personality types. Bantam; 1999. 99-100 p.
24. Riso DR, Hudson R. Understanding the enneagram: The practical guide to personality types. Houghton Mifflin Harcourt; 2000.

25. Allen J, Brock SA. Health Care Communication Using Personality Type: Patients are Different! Philadelphia: Taylor \& Francis; 2000. 